\title{
COMPARATIVE EVALUATION OF COMMERCIALLY AVAILABLE PROBIOTICS PRODUCTS
}

\author{
SUNEETI GORE1, ANJALI PAUL ${ }^{2}$, YASHADA BHAGWAT ${ }^{3}$ \\ Department of Microbiology, Fergusson College Pune 411004 \\ Email: suneetigore@gmail.com
}

Received: 28 Jul 2016, Revised and Accepted: 10 Oct 2016

\begin{abstract}
Objective: Probiotics are defined as live microorganisms that provide beneficial effects on human health by improving the balance of intestinal micro flora. Comparative evaluation of 10 (LB1-LB10) commercial probiotic preparations (available in and around Pune) was carried out on the basis of physical parameters, standard plate count (SPC), antibiotic sensitivity and antimicrobial production.

Methods: Effect of temperature, $\mathrm{pH}$ and bile tolerance of samples was carried out on de Man, Rogosa and Sharpe (MRS) medium and growth were determined by counting colony forming the unit (cfu) value of appropriate dilution after $24 \mathrm{~h}$ and $48 \mathrm{~h}$. Antibiotic sensitivity was carried out by disc diffusion assay. Antimicrobial activity was tested using Escherichia coli ,Staphylococcus aureus, Bacillus sp .and Klebsiella sp .by in vitro agar well diffusion method.

Results: All the 10 samples showed aggregation for SAT (Salt Aggregation Test) at $0.2 \mathrm{M}$ ammonium sulphate concentration .It was observed that $\mathrm{LB}, 8 \mathrm{LB} 9$ and LB 10were found to be the most promising probiotic product with respect to physical parameters. LB9 was found to be more antibiotic resistant as compared to LB10 and LB8 .Antibacterial production of LB9 was seen against all test organisms. Effects of all the 5 NSAIDs were checked and LB8 showed the resistance to all.
\end{abstract}

Conclusion: LB8 is the most effective probiotic product under adverse conditions followed by LB10 and LB9.

Keywords: Probiotics, Antibiotics, Bile salt, NSAIDs

(C) 2016 The Authors. Published by Innovare Academic Sciences Pvt Ltd. This is an open access article under the CC BY license (http://creativecommons.org/licenses/by/4.0/) DOI: http://dx.doi.org/10.22159/ijcpr.2017v9i2.17376

\section{INTRODUCTION}

Probiotics are live microorganisms which, when administered in adequate amounts, confer a health benefit on the host $[1,2]$. These live microbes can be formulated into many different types of products, including foods, drugs, and dietary supplements. Most of the probiotic species belong to genera, Lactic acid bacteria ( $L A B$, (Bacteroides, Clostridium, Fusobacterium Eubacterium, Ruminococcus, Peptococcus, Peptostreptococcus, and Bifidobacterium but the yeast) Saccharomyces cerevisiae (and some E. coli and Bacillus species are also used as probiotics .Ideal probiotic strains have special properties such as resistance to bile, hydrochloric acid, and pancreatic juice; the ability to tolerate stomach and duodenum conditions and gastric transport; stimulation of the immune system, thereby improving intestinal function via adhering and colonising the intestinal epithelium. In addition, probiotic strains competed with pathogens and modulated permeability, produced lactic acid, and exhibited anti-carcinogenic and anti-pathogenic activity [3]. These bacteria showed a symbiotic relationship with humans, by inhibiting the growth and attachment of harmful bacteria by producing bactericidal chemicals against them in the mucous membrane of gut epithelial cells. With the development of evidence regarding usefulness and safety of probiotics, these bacteria are replacing the traditional prophylactic and treatment regimes. The present target of any probiotic food product in terms of probiotic cell numbers is to have up to $10{ }^{7}$ colony-forming units (CFU)/g at the end of its shelf life.

Probiotics are used to assist the body's naturally occurring gut microbiota. Some probiotic preparations have been used to prevent diarrhoea caused by antibiotics, Studies have demonstrated probiotic effects on a variety of gastrointestinal and other disorders, including inflammatory bowel disease (IBD), irritable bowel syndrome (IBS), vaginal infections, and immune enhancement [2]. The probiotic beneficial effect for the host includes suppression of growth of pathogens, control of serum cholesterol level, modulation of the immune system, improvement of lactose digestion, synthesis of vitamins, increase in bio-availability of minerals and possible anti- carcinogenic activity [4]. Some probiotics have also been investigated in relation to atopic eczema, rheumatoid arthritis, and liver cirrhosis .Bacteriocins producing Lactic acid bacteria may also present a probiotic potential if capable of surviving the harsh conditions in the gastro-intestinal tract (GIT), including low $\mathrm{pH}$ and high concentrations of bile salts. Aggregation of LAB is an important feature in the evaluation of potential probiotic properties. While auto-aggregation may result in biofilm formation, co-aggregation with pathogens is important for elimination of non-desirable strains from the GIT. Another property which needs to be investigated for the probiotic potential of lactic acid bacteria is their antibiotic resistance. It is important to check for antibiotic resistance as they can act as potential reservoirs of resistance genes that can be transferred to other microorganisms, producing multidrug resistant strains [5].

Validation of probiotic contents in commercial products is needed to ensure consumer confidence. The term "probiotic" should be used only for products that meet the scientific criteria for this termnamely, products that contain an adequate dose of live microbes that have been documented in target-host studies to confer a health benefit [6].

The most common forms for probiotics are dairy products and probiotic-fortified foods. However, they are also available in tablets, capsules, and sachets containing the bacteria in freeze-dried form. The dose needed for probiotics varies greatly depending on the strain and product. Although many over-the-counter products deliver in the range of 1-10 billion cfu/dose, some products have been shown to be effective at lower levels, while some require substantially more .The global market for probiotics is estimated to exceed US $\$ 28.8$ billion by 2016 .

On 24th August 2007, the FDA issued rules that require current GMP for dietary supplements. Although these regulations do not address verification of efficacy claims, hopefully, they will improve the compositional quality (identity, purity, and strength) of probiotic supplements in the market [7]. But unfortunately, assessment of 
these products is limited by the lack of independent technical expertise and the expense of setting up the infrastructure to do such testing. Therefore, products are currently not subjected to stringent scrutiny; the manufacturers' claims are difficult to validate, and the regulatory body has no mechanism to do post-marketing surveillance. Standardising such evaluation with a validated method would provide a means to assess and compare products, confirm their contents and monitor the effect of storage on their shelf life.

In this paper Comparative evaluation of 10 (LB1-LB10) commercially available probiotic products (around Pune, Maharashtra, India) was carried out. The activity was checked on the basis of physical parameters such as standard plate count (SPC), Antibiotic sensitivity, Antimicrobial production, Acid and Bile tolerance, Effect of Temperature ,Salt Aggregation Test (SAT) and Effect of Nonsteroidal anti-inflammatory drugs (NSAIDs).

\section{MATERIALS AND METHODS}

All the products were purchased from the chemists in and around Pune, Maharashtra, India. All the media used in this study were manufactured by Hi Media ,India.

Collection and maintenance of probiotic samples:

Probiotic samples were collected on the basis of their availability and sale in the market. Ten samples were chosen for the experiment . Samples (LB1-LB10) were taken and enriched in the De Man Rogosa Sharpe's (MRS) broth and incubated at $37^{\circ} \mathrm{C}$ for $24 \mathrm{~h}$.

Table 1: Commercially available probiotics products samples

\begin{tabular}{|c|c|}
\hline Organisms Claimed by manufacturer & Sample number \\
\hline $\begin{array}{l}\text { Lactobacillus acidophilus- } 0.5 \text { billion, Lactobacillus rhamnosus- } 0.5 \text { billion, Bifidobacterium bifidum- } 0.5 \text { billion, Bifidobacterium } \\
\text { longum }-0.5 \text { billion, Streptococcus thermophillus }-0.25 \text { billion, Saccharomyces boulardii- } 0.25 \text { billion, }\end{array}$ & LB1 \\
\hline $\begin{array}{l}\text { Bifidobacterium longum-150 million, Lactobacillus acidophilus-350 million, Lactobacillus casei- } 350 \text { million, Variety } \\
\text { Rhamnosus-150million, Streptococcus thermophillus-200 million, Lactobacillus rhamnosus- } 200 \text { million }\end{array}$ & LB2 \\
\hline Lactic acid bacteria strain $10^{9}$ spores $\mathrm{cfu} / \mathrm{ml}$ & LB3 \\
\hline Lactic Acid Bacillus- $120 \times 10^{6}$ spores & LB4 \\
\hline Bacillus mesentricus-1 million, Clostridium butyricum-2 million, Streptococcus faecalis-30 million, Lactobacillus sporogenes- 50 million & LB5 \\
\hline $\begin{array}{l}\text { Lactobacillus acidophilus- } 0.24 \text { billion, Bifidobacterium bifidum- } 0.24 \text { billion, Bifidobacterium longum- } 0.24 \text { billion, Lactobacillus } \\
\text { rhamnosus- } 0.24 \text { billion, Saccharomyces boulardii- } 0.05 \text { billion, Streptococcus thermophillus- } 0.24 \text { billion }\end{array}$ & LB6 \\
\hline $\begin{array}{l}\text { Bifidobacterium longum }-5 \text { billion cfu, Streptococcus thermophillus }-5 \text { billion cfu, Lactobacillus acidophilus- } 2.5 \text { billion cfu, } \\
\text { Lactobacillus sporogenes }-2.5 \text { billion cfu, Total count- } 15 \text { billion cfu }\end{array}$ & LB7 \\
\hline $\begin{array}{l}\text { Lactobacillus sporogenes- } 2.5 \text { billion cells, Lactobacillus acidophilus }-2.5 \text { billion cells, Lactobacillus rhamnosus }-2.5 \text { billion cells, } \\
\text { Bifidobacterium bifidum }-2.5 \text { billion cells, Bifidobacterium longum }-2.5 \text { billion cells, Saccharomyces boulardii- } 2.5 \text { billion cells }\end{array}$ & LB8 \\
\hline $\begin{array}{l}\text { Streptococcus faecalis- } 30 \text { million spores, Clostridium butyricum-2 million spores, Bacillus mesentricus }-1 \text { million spores, } \\
\text { Lactobacillus sporogenes- } 50 \text { million spores }\end{array}$ & LB9 \\
\hline Lactobacillus casei strain, Shirota- 6.5 billion per $65 \mathrm{ml}$ bottle (conc. Of $10^{8} \mathrm{cfu} / \mathrm{ml}$ ) & LB10 \\
\hline
\end{tabular}

\section{- $\quad$ Effect of temperature}

The media used to study this parameter was MRS agar plates. Temperature tolerance of all samples was tested by inoculating overnight grown samples on MRS agar and incubating at $27^{\circ} \mathrm{C}, 37^{\circ} \mathrm{C}$ and $45{ }^{\circ} \mathrm{C}$ for $24 \mathrm{~h}$. The growth of samples was monitored by counting cfu/ml.

\section{- $\quad$ Bile tolerance}

To determine bile salt tolerance samples LB 1 to LB 10 were grown overnight in MRS broth. Sufficient cell suspension to give $10^{6}$ $\mathrm{CFU} / \mathrm{ml}$ concentration of each isolate was added into $10 \mathrm{ml}$ of fresh MRS media containing $1 \%, 2 \%$ and $3 \%$ of bile salts. The broths were incubated for $24 \mathrm{~h}$ and cell viability was determined by serial dilution and plating onto MRS agar after $24 \mathrm{~h}$ incubation.

\section{- Acid tolerance}

MRS agar plates and broth with different $\mathrm{pH}$ values were used in this study. Samples LB1 to LB 10 were added to MRS broth adjusted to $\mathrm{pH}$ 1,2 and 3 by using $0.1 \mathrm{~N} \mathrm{HCl}$. The initial bacterial concentration was $10^{6} \mathrm{CFU} / \mathrm{ml}$. The broths were incubated for $24 \mathrm{~h}$ at $37^{\circ} \mathrm{C}$ and cell viability was determined by serial dilution and plating onto MRS agar.

\section{- Antibiotic sensitivity}

MRS (De Mann Rogosa Sharpe's medium, Hi-media) Agar Antibiotics dodeca discs (Hi-Media, India) were used in this study. A disc diffusion assay was performed to study the antibiotic sensitivity of the samples (LB1-LB10). The samples were spread over the MRS agar plate. The antibiotics were supplied in the form of dodeca discs (Hi-Media, India) which included Cefpodoxime (CPD), Chloramphenicol (C), Vancomycin (VA), Streptomycin (S), Rifampicin (RIF), Levofloxacin (LE), Ceftriaxone (CTR), Clindamycin (CD), Augmentin (AMC), Amikacin (AK), Cefixime (CFM), and Tetracycline (TE). The zones of inhibition were recorded after incubation at $37^{\circ} \mathrm{C}$ for $24 \mathrm{~h}$.

\section{- Antimicrobial activity}

The samples were cultured in MRS broth overnight and the pathogens were grown in nutrient broth. $200 \mu \mathrm{l}$ of the test pathogens were spread onto the surface of Mueller-Hinton agar plates. Wells were punctured into the media. $100 \mu \mathrm{l}$ of CFS (cell-free supernatant) obtained by centrifugation of the culture at 10,000 rpm for 5 min using Kubota centrifuge and $\mathrm{pH}$ adjusted between 6 and 6.4 was added into the wells. The plates were left in side the refrigerator for $30 \mathrm{~min}$ and then incubated at $37{ }^{\circ} \mathrm{C}$ for $24 \mathrm{~h}$. The antimicrobial activity of the lactobacilli was determined in terms of the development of inhibition zones around the wells. The pathogens tested included Escherichia coli, Staphylococcus aureus, Klebsiella species (clinical isolates procured from local pathology laboratory) and Bacillus species (College laboratory isolate, isolated from soil).

\section{- $\quad$ Effect of NSAIDs}

Following Non-Steroidal Anti-inflammatory drugs (NSAIDs) with different concentrations were used in the study.

Table 2: Different NSAIDS and their concentrations used in the study

\begin{tabular}{ll}
\hline Concentration & NSAIDs \\
\hline $100 \mathrm{mg}$ & Aceclofenac \\
$500 \mathrm{mg}$ & Paracetamol \\
$100 \mathrm{mg}$ & Nimesulide \\
$400 \mathrm{mg}$ & Ibuprofen \\
$75 \mathrm{mg}$ & Aspirin \\
\hline
\end{tabular}


Effect of various NSAIDs on the growth of probiotic samples was tested using agar well diffusion assay. Probiotic samples were grown in MRS broth overnight at $37{ }^{\circ} \mathrm{C}$ and spread on MRS agar. Various concentrations of NSAIDs dissolved in an appropriate solvent was added to wells and the plates were left inside the refrigerator for 30 min and then incubated at $37^{\circ} \mathrm{C}$ for $24 \mathrm{~h}$. and zone of inhibition was recorded. The control well-containing solvent was also present on MRS agar plate.

\section{- $\quad$ Salt aggregation test (SAT)}

MRS broth containing Bacterial cells, Phosphate buffered saline (PBS) were used to study this parameter. Ammonium sulphate Solutions with different molarities (0.2-4.0) mol/l concentration of ammonium sulphate (M) giving aggregation the hydrophobic characteristic of the bacterial strains was determined according to the method reported by Johnson P. and Wadstrom T., (1984). Samples were grown in $10 \mathrm{ml}$ of MRS broth at $37{ }^{\circ} \mathrm{C}$ for $16 \mathrm{~h}$. Bacterial cells were harvested by centrifugation (3000 g for $15 \mathrm{~min}$ ), washed twice with phosphate-buffered saline (PBS) $\mathrm{pH} 7$ and suspended in PBS at a concentration of $10^{7}$ cells $/ \mathrm{ml}$. Bacterial cell suspensions $(25 \mu \mathrm{L})$ were mixed with equal volumes of ammonium sulphate of various molarities $(0.2-4.0 \mathrm{~mol} / \mathrm{l})$ on microscopic glass slides. The lowest concentration of ammonium sulphate giving a visible aggregation was scored as the SAT hydrophobicity value.

\section{RESULTS}

All the commercially available probiotic samples were suspended in sterile distilled water and serially diluted up to 10- . ${ }^{9}$ The colonies obtained on MRS agar plates were counted and the standard plate count of these samples is given in tabular form.

Table 3: SPC of the probiotics samples

\begin{tabular}{|c|c|c|c|c|}
\hline \multicolumn{4}{|c|}{ Standard plate contributions } & \multirow[t]{2}{*}{ Samples } \\
\hline 9-10 & $8-10$ & $7-10$ & 6-10 & \\
\hline $10 \times 10^{9}$ & $40 \times 10^{8}$ & $100 \times 10^{7}$ & $380 \times 10^{6}$ & LB 1 \\
\hline $60 \times 10^{9}$ & $120 \times 10^{8}$ & $260 \times 10^{7}$ & $300 \times 10^{6}$ & LB 2 \\
\hline $13 \times 10^{9}$ & $36 \times 10^{8}$ & $84 \times 10^{7}$ & $120 \times 10^{6}$ & LB 3 \\
\hline $2 \times 10^{9}$ & $13 \times 10^{8}$ & $110 \times 10^{7}$ & $190 \times 10^{6}$ & LB 4 \\
\hline $8 \times 10^{9}$ & $18 \times 10^{8}$ & $40 \times 10^{7}$ & $210 \times 10^{6}$ & LB 5 \\
\hline $7 \times 10^{9}$ & $16 \times 10^{8}$ & $130 \times 10^{7}$ & $240 \times 10^{6}$ & LB 6 \\
\hline $11 \times 10^{9}$ & $46 \times 10^{8}$ & $96 \times 10^{7}$ & $140 \times 10^{6}$ & LB 7 \\
\hline $10 \times 10^{9}$ & $22 \times 10^{8}$ & $168 \times 10^{7}$ & $176 \times 10^{6}$ & LB 8 \\
\hline $32 \times 10^{9}$ & $60 \times 10^{8}$ & $180 \times 10^{7}$ & $280 \times 10^{6}$ & LB 9 \\
\hline $34 \times 10^{9}$ & $38 \times 10^{8}$ & $61 \times 10^{7}$ & $80 \times 10^{6}$ & LB 10 \\
\hline
\end{tabular}

\section{- $\quad$ Effect of temperature}

All the 10 (LB1-LB10) samples were able to grow at $27{ }^{\circ} \mathrm{C}, 37{ }^{\circ} \mathrm{C}$ while sample LB1, LB2, LB6, LB 8 and LB10 showed very little growth $45^{\circ} \mathrm{C}$. Considering the human body temperature and the optimum temperature obtained, all further experiments were carried out at $37^{\circ} \mathrm{C}$. The colony forming units $/ \mathrm{ml}$ are shown in the table for each isolate at three different temperatures.

Table 4: Effect of temperature on colony forming units of probiotics

\begin{tabular}{|c|c|c|c|c|c|c|c|c|c|c|}
\hline LB10 & LB9 & LB8 & LB7 & LB6 & LB5 & LB4 & LB3 & LB2 & LB1 & Temp \\
\hline $10^{4}$ & $10^{3}$ & $10^{3}$ & $10^{2}$ & $10^{1}$ & $10^{3}$ & $10^{4}$ & $10^{4}$ & $10^{1}$ & $10^{1}$ & $27^{\circ} \mathrm{C}$ \\
\hline $10^{4}$ & $10^{4}$ & $10^{4}$ & $10^{3}$ & $10^{2}$ & $10^{3}$ & $10^{4}$ & $10^{4}$ & $10^{2}$ & $10^{3}$ & $37^{\circ} \mathrm{C}$ \\
\hline $10^{1}$ & $10^{4}$ & $10^{1}$ & $10^{3}$ & $10^{1}$ & $10^{3}$ & $10^{3}$ & $10^{4}$ & $10^{1}$ & $10^{1}$ & $45^{\circ} \mathrm{C}$ \\
\hline
\end{tabular}

\section{- $\quad$ Effect of bile}

The probiotic cultures were exposed to various concentrations of bile salts $(1 \%, 2 \%$ and $3 \%)$. At higher concentration of bile salt (3\%) sample LB8 was found to be more bile tolerant followed by LB2, LB6 and LB9. The growth of organisms (LB 1 to LB 10) in terms of the optical density is shown in the table at different concentrations of bile salts.

Table 5: Effect of bile salt concentration on the growth of the probiotics organisms

\begin{tabular}{lllllllllll}
\hline LB10 & LB9 & LB8 & LB7 & LB6 & LB5 & LB4 & LB3 & LB2 & LB1 & Bile Conc (\%) . \\
\hline 0.4 & 0.1 & 0.8 & 0.1 & 0.4 & 0.4 & 0.1 & 0.4 & 0.8 & 0.4 & 1 \\
0.2 & 0.2 & 0.9 & 0.8 & 0.5 & 0.5 & 0.4 & 0.3 & 0.4 & 0.1 & 2 \\
0.1 & 0.1 & 0.8 & 0.4 & 0.1 & 0.5 & 0.5 & 0.5 & 0.5 & 0.2 & 3 \\
\hline
\end{tabular}

\section{- $\quad$ Acid tolerance}

The probiotic samples were exposed to different $\mathrm{pH}$ values $(1,2$ and 3 ). It was observed that all the probiotic samples could tolerate these $\mathrm{pH}$ values. At $\mathrm{pH} 1$ sample $1,3,4,9,10$ showed reductions in growth by 20 percent. At $\mathrm{pH} 3$, all the cultures except 3 showed good growth. At pH 2 all the samples except 1 showed good growth.

Table 6: Effect of $\mathrm{pH}$ on the growth of probiotics organisms

\begin{tabular}{|c|c|c|c|c|c|c|c|c|c|c|}
\hline LB10 & LB9 & LB8 & LB7 & LB6 & LB5 & LB4 & LB3 & LB2 & LB1 & pH \\
\hline 0.1 & 0.1 & 0.8 & 0.4 & 0.4 & 0.4 & 0.2 & 0.2 & 0.4 & 0.1 & 1 \\
\hline 0.2 & 0.2 & 0.7 & 0.7 & 0.8 & 0.8 & 0.8 & 0.8 & 0.4 & 0.1 & 2 \\
\hline 0.3 & 0.4 & 0.8 & 0.8 & 0.7 & 0.9 & 0.4 & 0.1 & 0.5 & 0.2 & 3 \\
\hline
\end{tabular}




\section{- Antibiotic sensitivity}

All the 10 isolates were subjected to antibiotic susceptibility test. LB1 was found to be resistant to CD, CFM, VA and CPD and LB10 found to be resistant to VA, CPD and C while LB2 was sensitive to most of the antibiotics.

All the samples were resistant to CPD except sample 6 and 8.

Table 7: Antibiotic sensitivity pattern of the probiotics organisms

\begin{tabular}{|c|c|c|c|c|c|c|c|c|c|c|c|}
\hline \multicolumn{10}{|c|}{ Diameter of zone of inhibition (mm) } & \multirow{2}{*}{$\begin{array}{l}\text { Concentration) in } \\
\text { mcg) }\end{array}$} & \multirow[t]{2}{*}{ Antibiotics (symbols) } \\
\hline LB10 & LB9 & LB8 & LB7 & LB6 & LB5 & LB4 & LB3 & LB2 & LB1 & & \\
\hline 11 & 10 & 30 & 21 & 20 & 19 & 27 & 16 & 25 & 19 & 30 & $\operatorname{Amikacin}(\mathrm{AK})$ \\
\hline 20 & 16 & 33 & 22 & 30 & 15 & 18 & 6 & 8 & 9 & 30 & Augmentin(AMC) \\
\hline 20 & 15 & 27 & ND & 25 & 20 & 25 & 30 & 22 & ND & 2 & Clindamycin(CD) \\
\hline 23 & 20 & 12 & ND & 30 & 24 & 20 & 14 & 31 & 13 & 30 & Ceftriaxone(CTR) \\
\hline 15 & 24 & 30 & 34 & 30 & 40 & 38 & 10 & 32 & 35 & 5 & Levofloxacin(LE) \\
\hline 14 & 14 & 30 & 40 & 25 & 21 & 25 & 15 & 27 & 13 & 5 & Rifampicin(RIF) \\
\hline 23 & 24 & 25 & 24 & 32 & 28 & 26 & 20 & 27 & 15 & 30 & Tetracycline(TE) \\
\hline 21 & ND & 30 & 22 & 20 & ND & ND & ND & 11 & ND & 5 & Cefixime(CFM) \\
\hline ND & 20 & 25 & 13 & 12 & 23 & 21 & 6 & 20 & ND & 30 & Vancomycin(VA) \\
\hline ND & 35 & 25 & 41 & 9 & 24 & 27 & 28 & 35 & 17 & 30 & Chloramphenicol(C) \\
\hline ND & ND & 22 & ND & 12 & ND & ND & ND & ND & ND & 10 & Cefpodoxime(CPD) \\
\hline 15 & 10 & ND & 24 & ND & 30 & 26 & 18 & 29 & 21 & 10 & Streptomycin(S) \\
\hline
\end{tabular}

ND: No zone of inhibition detected

Table 8: Antibacterial activity of the probiotic organisms against indicator organisms

\begin{tabular}{|c|c|c|c|c|}
\hline \multicolumn{4}{|c|}{ Test organisms diameter of zone of inhibition in $\mathbf{m m}$} & \multirow[t]{2}{*}{ Isolates } \\
\hline Klebsiella spp. & E. coli & Staphylococcus aureus & Bacillus spp. & \\
\hline ND & ND & 11 & ND & LB 1 \\
\hline ND & ND & 6 & ND & LB 2 \\
\hline 4 & 6 & ND & ND & LB 3 \\
\hline 3 & ND & ND & ND & LB 4 \\
\hline 4 & ND & 4 & ND & LB 5 \\
\hline 7 & 4 & ND & ND & LB 6 \\
\hline 8 & 11 & 4 & ND & LB 7 \\
\hline ND & ND & 13 & ND & LB 8 \\
\hline 12 & 7 & 10 & 8 & LB 9 \\
\hline 12 & ND & 15 & 11 & LB 10 \\
\hline
\end{tabular}

ND: No zone of inhibition detected

\section{- Antimicrobial activity}

Antibacterial production by LB9 was seen against all the test organisms used in the study.

\section{- $\quad$ Effect of NSAIDs}

When five different Non-steroidal anti-inflammatory drugs were tested against probiotic samples, it was observed that all these samples are sensitive to anti-inflammatory compounds and showed a zone of inhibition in the presence of them. Sample LB 8, LB 9 and LB 10 were found to be resistant to these drugs as the zone of inhibition was not observed in these plates.

\section{- Salt aggregation test}

All the samples undergone SAT (Salt Aggregation Test) to check hydrophobicity and at $0.2 \mathrm{M}$ ammonium sulphate concentration.

All the isolates except LB 2 and LB 6 showed aggregation.

Table 9: Effect of different NSAIDs on the probiotic organisms

\begin{tabular}{|c|c|c|c|c|c|}
\hline \multicolumn{5}{|c|}{ Effect of non-steroidal anti-inflammatory drugs )NSAIDs) } & \multirow[t]{2}{*}{ Probiotic Samples } \\
\hline Aspirin & Ibuprofen & Nimesulide & Paracetamol & Aceclofenac & \\
\hline+ & + & + & + & + & LB1 \\
\hline+ & + & + & + & + & LB2 \\
\hline+ & + & + & + & + & LB3 \\
\hline+ & + & + & + & + & LB4 \\
\hline+ & + & + & + & + & LB5 \\
\hline+ & + & + & + & + & LB6 \\
\hline+ & + & + & + & + & LB7 \\
\hline- & - & - & - & - & LB8 \\
\hline- & - & - & - & - & LB9 \\
\hline - & - & - & - & - & LB10 \\
\hline
\end{tabular}

\footnotetext{
$=$ " +"Zone of inhibition, ="-"No zone of inhibition
} 
Table 10: Salt aggregation test of the probiotic organisms

\begin{tabular}{llllllllllll}
\hline \multicolumn{1}{l}{ Concentration of ammonium sulphate giving aggregation } & \multicolumn{1}{c}{ Concentration of ammonium sulphate (M) } \\
\cline { 1 - 7 } LB 10 & LB 9 & LB 8 & LB 7 & LB 6 & LB 5 & LB 4 & LB 3 & LB 2 & LB 1 & \\
\hline++ & + & ++ & ++ & - & + & ++ & +++ & - & + & 0.2 \\
++ & + & +++ & ++ & - & + & ++ & +++ & - & + & 0.3 \\
++ & + & +++ & - & - & ++ & +++ & +++ & - & - & 0.4 \\
- & - & +++ & ++ & - & ++ & ++ & +++ & - & + & 0.5 \\
\hline
\end{tabular}

\section{CONCLUSION}

The ability of probiotic bacteria to survive the harsh environments encountered during processing and gastrointestinal transit has been a major factor in their selection criteria. Probiotics are mostly delivered in a food system and must be tolerant to harsh conditions to confer its full effect. Considering the significant rise in the annual consumption of probiotic products, it is important that such products are well-documented and regarding safe and functional [8]. In this comparative study profile of probiotic bacteria isolated from different commercial probiotic products was done. Firstly, ten (LB1-LB10) probiotic samples were procured. They were subjected to screening for potential probiotic abilities. All the samples were able to survive the low $\mathrm{pH}(\mathrm{pH} 1, \mathrm{pH} 2$ and $\mathrm{pH} 3)$ conditions but at pH 2 most of the probiotic bacteria showed viability and activity. However, at $\mathrm{pH} 1$ viability of the probiotic bacteria was low as compared to $\mathrm{pH} 2$ and $\mathrm{pH} 3$. In similar studies, it was found that probiotic bacteria were able to survive low $\mathrm{pH}$ conditions. Bile tolerance was observed by selecting a range of bile concentration $(1 \%, 2 \%$ and $3 \%)$. All the isolates were tolerant to the bile concentration, however, higher tolerance was observed at $1 \%$ bile concentration and with an increase in the bile salt concentration, growth of probiotic bacteria decreases. In most of the studies, it was observed that at $0.3 \%$ bile salt concentration maximum tolerance of probiotic bacteria was observed. Regarding antibiotic sensitivity, most of the samples showed resistance towards Clindamycin (CD), Cefpodoxime (CPD) and Cefixime (CFM). LB1 and LB10 showed resistance against Vancomycin (VA) and Cefpodoxime (CPD). All the 10 samples were sensitive to Tetracycline (TE), Rifampicin (RIF), Chloramphenicol (C) and Levofloxacin (LE). LB2 was found sensitive to most of the antibiotics. In previous studies, it was shown that most of the probiotic bacteria are sensitive to Chloramphenicol (C) and Ampicillin. According to antimicrobial activity, most of the probiotic bacteria showed antimicrobial activity against Staphylococcus aureus and weak inhibition was shown against Bacillus sp. In previous studies, it was reported that probiotic bacteria show antimicrobial activity against S. aureus [9]. From this study, it was observed that LB9 showed antimicrobial activity against all the pathogenic bacteria used in this study. Hydrophobicity by using SAT (Salt Aggregation Test) was reported by many studies [9] and in this study, all the 10 samples (LB1-LB10) showed aggregation at $0.2 \mathrm{M}$ Ammonium sulphate and except LB2 and LB6 all the other 8 samples showed aggregation at a various range of ammonium sulphate concentration (0.3-0.5M). Effects of five different NSAIDs were checked against all the ten (LB1-LB10) samples. LB8, LB9 and LB 10 were resistant to Aceclofenac, Paracetamol, Nimesulide, Ibuprofen and Aspirin and remaining all the samples showed susceptibility to all the different NSAIDs used in this study. LB8 was most resistant to Aspirin and Nimesulide. In previous studies it was shown that most of the probiotic bacteria were resistant to Aspirin ,Aceclofenac and Nimesulide and result of this study correlate with the previously reported work [9].

Probiotic microorganisms act through several interrelated mechanisms to promote health at the molecular level [10.[The health benefits of probiotics have always been investigated with regard to their capability to sustain their availability, viability, digestibility, and rendering of their health benefits to the host .They conquer potentially dangerous micro-organisms in the intestine, reducing the risk of infection or toxin-mediated diseases .Moreover, our expectations of probiotic bacteria have perhaps become the most demanding for any bacterial group to date. Probiotics are available to consumers mainly in the form of foods and as dietary supplements. Additionally, the products have been introduced to healthcare professionals with a variety of therapeutic claims for health and benefit, often with extrapolated clinical evidence of efficacy. In conclusion of this work, it was found that probiotic sample 8 was superior probiotic amongst 10 tested samples followed by LB 10 and LB 9.

\section{CONFLICT OF INTERESTS}

All authors have none to declare

\section{REFERENCES}

1. World Health Organization.Guidelines for the evaluation of probi otics in the food; 2002. Available from:www.who.int/ food safety/fs_management/en/probiotic_guidelines.pdf WHO. [Last accessed on 20 Jun 2016]

2. Guarner F, Khan AG. Probiotics and prebiotics World Gastroenterology Organization, Practice Guideline; 2003.

3. Fooladi AAI, Hosseini HM, Nourani MR, Khani S, Alavian SM. Probiotic as a Novel treatment strategy against liver disease. Hepat Mon 2013;13:e752.

4. Furtado DN, Svetoslav D Todorov. Bacteriocinogenic Lactococcus lactis subsp. lactis DF04Mi isolated from goat milk: evaluation of the probiotic potential. Braz J Microbiol 2014;3:1047-54.

5. Dicks LMT, Todorov SD, Franco BDGM. Current status of antibiotic resistance in lactic acid bacteria. In: Bonilla AR, Muniz KP. editors. Antibiotic resistance: causes and risk factors, mechanisms and alternatives pharmacology-research, Safety Testing and Regulation. Nova Publisher; New York: 2011. p. 379-425.

6. Sanders ME. Probiotics: definition, sources, selection and uses. Clin Infect Dis 2008;46 Suppl 2:S58-S61.

7. Schlundt J. Health and nutritional properties of probiotics in food including powder milk with live lactic acid bacteria. Report of a Joint FAO/WHO expert consultation on evaluation of health and nutritional properties of probiotics in food including powder milk with live lactic acid bacteria. FAO/WHO; 2012.

8. E Elliott, $\mathrm{K}$ Teversham. An evaluation of nine probiotics available in South Africa. South African Med J 2004;94:121-4.

9. Amin S, Tale VS, Bhadekar RK. Evaluation of the effect of nonsteroidal anti-inflammatory drugs on the growth of probiotics. Int J Pure Appl Sci Technol 2014;20:25-35.

10. Thomas CM. Probiotics-host communication: modulation of signalling pathways in the intestine. Gut Microbes 2010,1:148-63.

\section{How to cite this article}

- Suneeti Gore, Anjali Paul, Yashada Bhagwat. Comparative evaluation of commercially available probiotics products. Int J Curr Pharm Res 2017;9(2):26-30. 